\title{
Health Matters: The Dawson and Harrington \\ Families at Home ${ }^{1}$
}

\section{by Annmarie Adams and Peter Gossage}

\begin{abstract}
This article focuses on the spaces associated with the extended family of John William and Margaret Dawson, particularly their nine-room, two-storey home at 293 University Street in Montreal. The Dawsons purchased their retirement house in 1893, as well as the house next door for their daughter, Anna, her busband, chemistry professor Bernard Harrington, and their eight children. The two houses are rich sources on bow two generations lived together and separately simultaneously. The rich archival legacy of the Dawsons illustrates how Anna Harrington organized her house to regulate her children's health, especially that of her son Eric, who suffered from a series of ailments and died in 1894.

"Health Matters" contributes to our growing understanding of the architecture and material culture of childhood by modeling an interdisciplinary method drawn from architectural and social history. Secondly, it argues that mothers directed their movements according to the condition of children; furthermore, it looks at how children organized bousehold and backyard spaces, completely independently from adults; and finally, it shows how extended families constructed sophisticated boundaries while living in a decidedly fluid, premodern way.
\end{abstract}

\section{RESUMÉ}

Ce texte présente une exploration des espaces associés à la famille élargie de Jobn William et Margaret Dawson, dont notamment leur maison de neuf pièces sur deux étages, située au 293, rue University à Montréal. Les Dawson acquièrent cette maison en 1893 pour y vivre pendant leur retraite. Ils achètent en même temps la maison voisine pour héberger leur fille Anna, son mari Bernard Harrington, professeur de chimie, et leurs buit enfants. Les deux maisons constituent une documentation très riche sur la manière dont deux générations peuvent vivre ensemble et séparément en même temps. Le patrimoine archivistique de la famille Dawson fait ressortir la manière dont Anna Harrington organise sa vie domestique afin de réguler la santé de ses enfants et surtout celle de son fils Eric, qui souffre d'une série de maladies avant d'en mourir en 1894.

À partir d'une méthode interdisciplinaire située au carrefour de l'bistoire sociale et de l'bistoire de l'architecture, "Health Matters" ajoute à nos connaissances de l'architecture et de la culture matérielle de l'enfance. Le texte suggère à quel point les mères agissent en fonction de la condition des enfants et démontre comment les enfants organisent parfois, à l'abri de toute intervention des parents, des espaces de la maison et du jardin. Enfin, il démontre la façon dont la famille élargie peut ériger des frontières internes complexes, tout en vivant d'une manière fluide, définitivement pré-moderne.

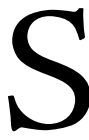
ir John William Dawson was a remarkable man. As a geologist, he is best known for his early fossil plants and his identification (later disproven) of a coral, Eozoön canadense ("dawn animal of Canada"), the oldest nonplant fossil known in $1864 .^{2}$ Dawson was the only individual ever to serve as president of both the American and British Associations for the 


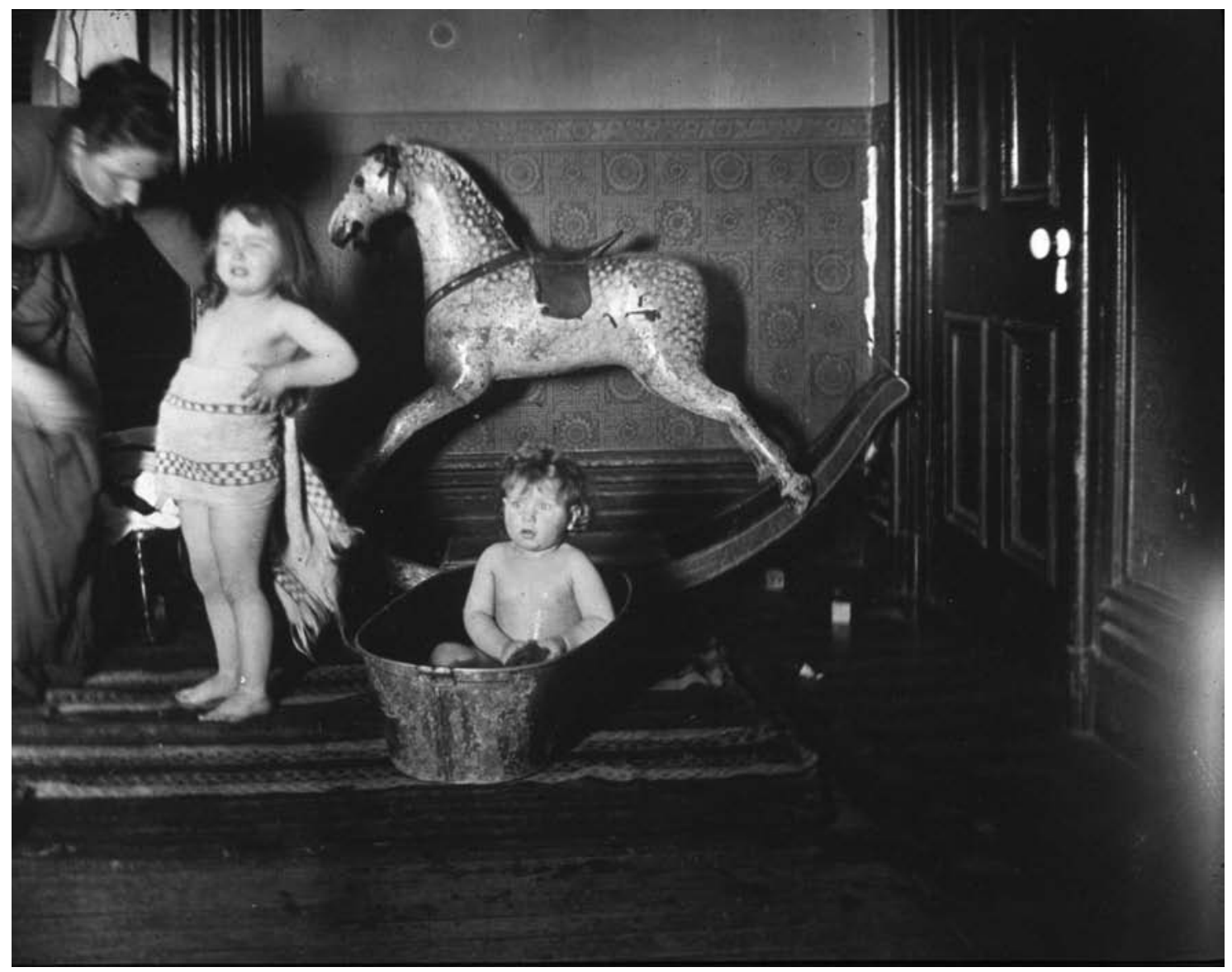

Figure 1. Anna, Lois, and Constance in bath, at Walbrae Place, with rocking horse, Feb. 1892. McGill University Archives, PA027196.

Advancement of Science; he was knighted in 1884 and he was the first President of the Royal Society of Canada (founded 1882). As Principal of McGill University from 1855-1893, he is credited with establishing the foundations of modern science in Canada. His administration admitted women to McGill and established the university as a leading research institution. Not surprisingly, he is the subject of several detailed biographies and of numerous scholarly articles. ${ }^{3}$

The Dawson name and legacy are also ubiquitous on the McGill University campus. The family's residence until the late 1870s was in the East wing of the Arts Building, later renamed Dawson Hall. ${ }^{4}$ Dawson's personal collection of shells, fossils, and other objects still comprises the core of the Redpath Museum's remarkable inventory. And as a record of the varied accomplishments of its best known principal, the McGill University Archives boast an astonishing 15 linear metres of Dawsonia. ${ }^{5}$

This article sidesteps this official, public side of Dawson's life. Instead, we draw on the sheer comprehensiveness of his vast archival legacy to explore a subject only tangentially related to his work as a geologist, collector, and educator: sick children at home. Scholars have paid some attention to Dawson's private life as a young man. ${ }^{6}$ But his retirement years are so thoroughly neglected that when, in the early 1960s, McGill University purchased as an investment property the house in which he had lived his last six years, 


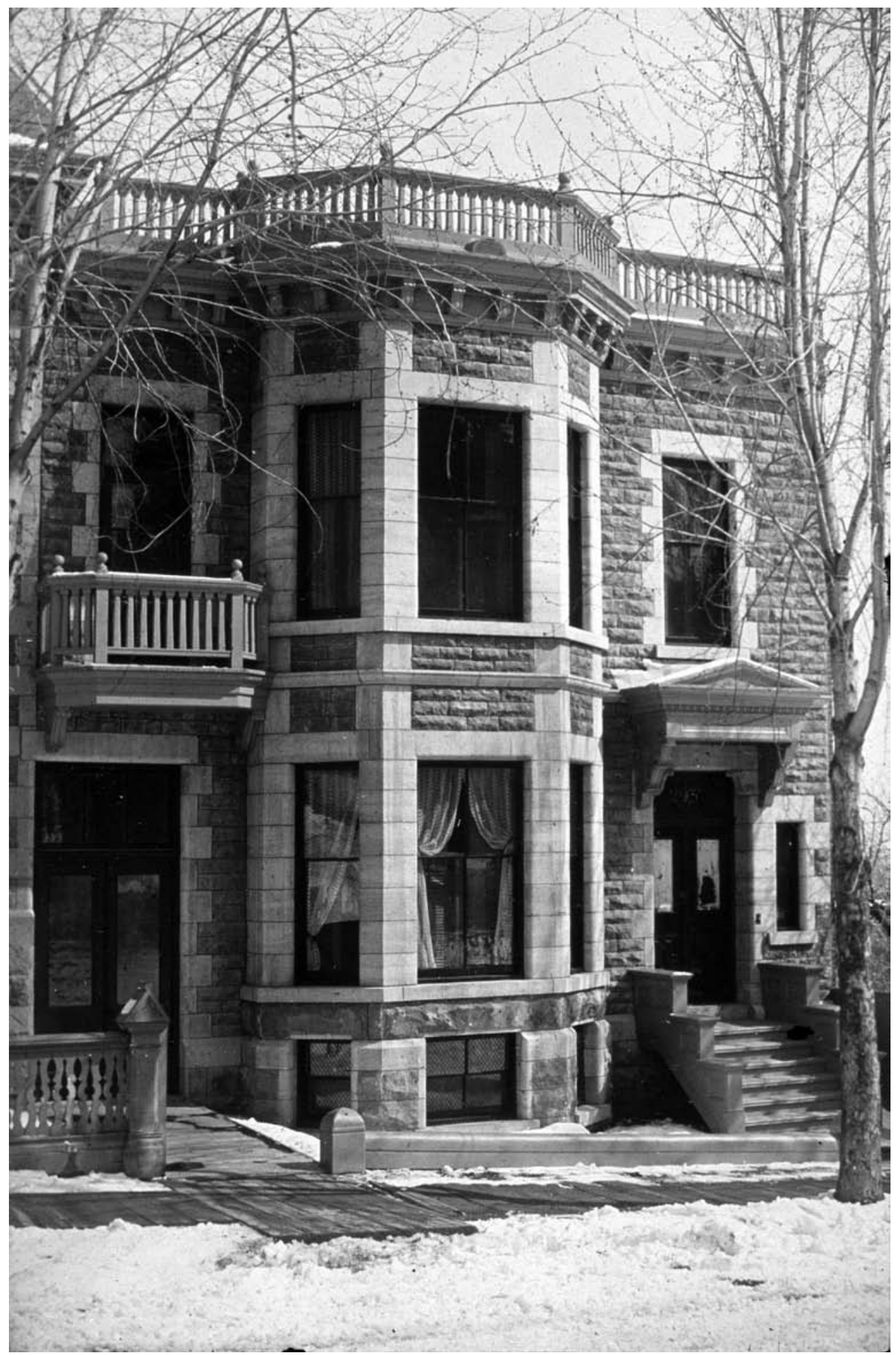

Figure 2. Note the upper railing, which may indicate the roof was used as an outdoor living area. 293 University Street 1893. McGill University Archives, PA027196. 


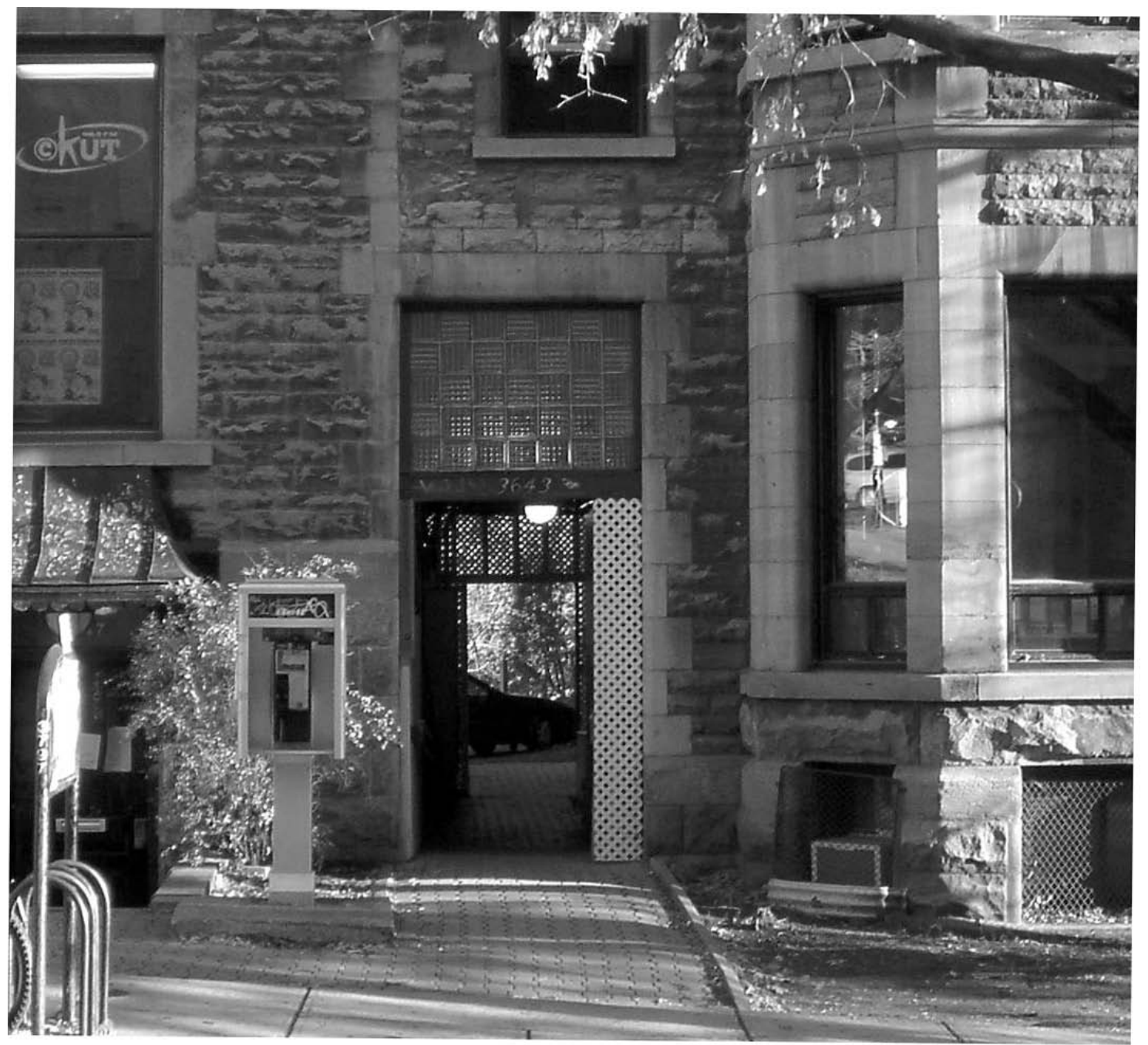

Figure 3. University Street (now 3641 University). Note the unusual passageway between the Harrington and Dawson house, leading to the shared back garden. Ricardo Castro. McGill University Archives, PA027196. 
university administrators were unaware that it had ever been his home. ${ }^{7}$

With children and their health squarely in the foreground, this article crosses the thresholds of the Dawson family's private spaces in retirement, as well as the photos and extraordinarily detailed letters written by his wife, Lady Margaret Ann Young Mercer Dawson, their children and grandchildren. Both visual and textual sources for this study abound in the McGill collections. Many images reveal the family's life beyond the university. A stunning photograph (Fig. 1) of 1892, for example, extracted from grandson George "Eric" Harrington's photo album, shows Dawson's daughter (and Eric's mother), Anna Harrington, bathing her two daughters Lois and Constance, in February 1892. ${ }^{8}$ Likewise, the archival record and architectural evidence of the Dawsons' life in their nine-room, twostorey townhouse in Montreal, 293 University Street (Fig. 2) is an extraordinarily detailed record of extended family relations in the English Protestant elite of Canada's largest city at the turn of the twentieth century. ${ }^{9}$

Sir William and Lady Dawson commissioned their retirement house from architect Andrew Taylor in 1893 or $1894 .{ }^{10}$ Also in 1893 , when Dawson retired, the couple purchased the much larger, sixteen-room house next door, at 295 University Street (Fig. 3), which was probably built in 1873 or $1874 .{ }^{11}$ The building was acquired as a home for Anna, her husband, McGill chemistry professor Bernard Harrington (married 1876), and their eight children. ${ }^{12}$ The Dawsons clearly conceived of their purpose-built retirement home as an addition to their daughter's house, a relationship most evident from the design of an unusual outdoor passageway, which probably also linked the houses internally. ${ }^{13}$ Lady Dawson described the proximity of the new house to Anna's in a letter to her son George Mercer Dawson in May 1893: "Papa at the same time has secured a small lot adjoining lest he should decide to add a few rooms for our use, these wd have a separate entrance from the street and a private door by which we could enter into A's house so that we cd take our meals with her." ${ }^{14}$ Today the internal link between the two houses is unclear, and none of the surviving architectural evidence allows us to clarify these spatial relationships any further. In any case, the passageway and the shared garden to which it led make the two houses an especially good spatial source on how three generations lived together and separately simultaneously, even though the plans of both houses were typical, Victorian arrangements, featuring a myriad of isolated, use- and gender-specific rooms accessible from a central hall or corridor. ${ }^{15}$

The major arguments of this research stem directly from the fluidity of these household arrangements. This case study of the DawsonHarrington families showcases the supreme importance of health concerns at this time and the role of privileged mothers like Anna and older children, especially daughters, in translating such concerns into action. Montrealers at the turn of the twentieth century had good reason to be concerned about health, and particularly the health of children. In the first five years of the new century, the city had infant mortality rates of 275 per thousand live births, among the highest on the continent. ${ }^{16}$ Congenital and contagious diseases carried off thousands more children each year, leaving a strong sense, at least in the social-history literature, in which children were the most tragic victims of the public health problems linked to rapid urban and industrial development. ${ }^{17}$ Without contesting the health risks associated with urban life in Victorian Canada, especially for those less privileged than the Dawsons, our approach places the emphasis elsewhere: on children's active role in the use of spatial strategies to deal with health risks. In so doing, it also calls into question the cultural construction of rural places as necessarily healthier than city houses and the passivity and helplessness of children, even privileged, teenaged children in this period. Was being sick 
an opportunity to escape the realm of childhood described by architectural historian Abigail Van Slyck as "the performance of childness" ?18 We will argue that young Clare Harrington, in this case study, acted as a significant bridge between the worlds of children and their parents. She not only cared for her siblings and reported on their health, but also managed servants and acted as a link to other Montreal households. In this respect, Clare was the human complement to the extended family's remarkably supple living arrangements.

This case study of the Dawson-Harringtons, moreover, is intended to challenge several assumptions expressed in various ways by historians of the family and medicine: that the Victorian house and family were insulated, that children were islanded or separated from their parents, that middle-class mothers with sick children were largely confined at home, and that domestic medicine lagged behind or differed significantly from that practiced in the urban hospital. The study is also intended to confirm and alter some of the hypotheses we and other scholars have made from normative and nominative sources. In her 1992 University of California at Berkeley dissertation and subsequent 1996 book, Architecture in the Family Way, Annmarie Adams explored the female regulation of the healthy house, including the special accommodations made for sick family members, and the spatial confinement of women following childbirth. ${ }^{19}$ One limitation of the book was that it relied almost exclusively on prescriptive sources, rather than specific accounts of sickness at home, such as the Dawson archives. Detailed letters to and from the Harrington children suggest that late nineteenth-century prescriptive literature in general actually contradicted rather than reflected reality. Were Victorian mothers warned to keep sick children at home, for example, because it was an infrequent practice? New research on hospital architecture, too, shows how sick children were largely invisible rather than segregated or islanded in the general

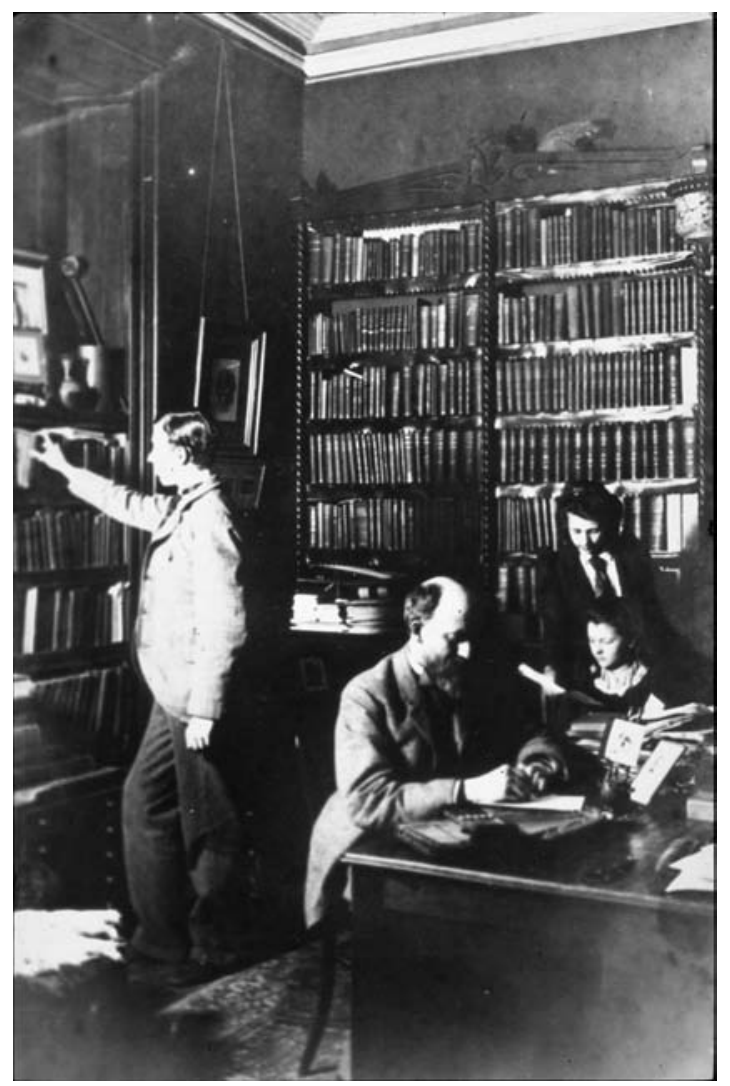

Figure 4. An undated photo of the library at Walbrae Place, the Harrington family's home until 1893, shows Bernard Harrington, with his children Eric, Ruth, and Clare. Perhaps because he was so ill throughout his short life, photographs of Eric are quite rare. McGill University Archives, PA027196.

hospital until about World War I. Even purposebuilt hospitals for children in the interwar period provided few technologies or medical spaces that differed from those of purpose-built hospitals for adults, reflecting the ambiguous relationship of pediatrics to the scientific ambitions of other medical specialities. ${ }^{20}$

This research also builds on one of the arguments in Peter Gossage's book-length study of families in Saint-Hyacinthe, Quebec, a small manufacturing and market town located 50 kilometres east of Montreal. ${ }^{21}$ In a chapter built around links from local marriage registers to manuscript census returns from 1871, 1881, and 
1891, he found that young married couples, most of them French Canadian, chose to live very near to their parents, without "doubling up" in the same dwelling. ${ }^{22}$ Families in Transition, however, did not move beyond the routinely generated sources of historical demography to explore the spatial contours of this widespread practice (as reflected, for example, in house plans and photographs) or the social and psychological dimensions accessible only through diaries, letters, and other private papers. The richly documented DawsonHarrington family lends support to those earlier findings, while permitting close attention to the ways in which residential propinquity allowed extended families to cope both with daily tensions and with major crises such as illness and death.

Ultimately, this article represents the second case study in an interdisciplinary, multi-year project by Adams and Gossage to explore the intersection of architectural and family histories in nineteenth- and early twentieth-century Quebec. Following the publication of a first example which dealt with the issue of remarriage and focused on the Dessaulles house of 185457 in Saint-Hyacinthe, our working hypothesis is that as family tensions rise, girls and women gain control of domestic space. In the wake of her father's remarriage, the young Henriette Dessaulles took an extremely active part in reordering her domestic space, thus predating Virginia Woolf's emancipatory call for a "room of one's own" by several decades. ${ }^{23}$

\section{THE SICK CHILD AT HOME}

Sick children were a constant concern of Anna Harrington's. Particularly worrisome was the health of her first-born son, Eric, who eventually died at the age of seventeen (fig. 4). Eric had suffered from a number of ailments during his 17 years, and there is strong circumstantial evidence that he died of tuberculosis. But none of the many family letters that speculate on Eric's prognosis state explicitly that the teenager had the disease. In June and July 1893 he was described as suffering from rheumatism. ${ }^{24}$ One letter refers to a "family inheritance" with regards to Eric's condition, as diagnosed by Anna's physician-brother Rankine, perhaps an allusion to a genetic condition. In a letter dated July 21, 1894, from Lady Dawson to Anna's brother George, "Rankine I fear is only too likely to be correct in his opinion of the family inheritance. His diagnosis of Eric's case is confirmed by Bernard now that he has joined Anna $\&$ Eric $\&$ has heard the opinion of a nice painstaking, sensible $\&$ sincere local medicine man who has made an examination of Eric's lungs-he finds disease well established $\&$ in an advanced stages." 25 A month earlier, George Dawson (not a physician) apparently said Eric had tubercular deposit in the lungs. ${ }^{26}$ And to confuse things even more, Anna says, "I don't know what to say about Eric, this whole disease is new to me $\&$ I cannot understand what the doctors mean by what they say." ${ }^{27}$ The letters also reveal that many individuals offered money to Anna for Eric, including her brother George who offered "unlimited cash," insisting that Anna get a nurse for Eric, at his expense. ${ }^{28}$

Much of Anna's domestic life in the early 1890s was spent away from home due to Eric's deteriorating condition. The family tension around Eric's illness affected the way Anna understood the house, and the way she wanted it organized. Her domestic environments, that is, were determined by the decisions made about Eric's illness and where he should be. Fortunately for us, because Eric's illness meant Anna was often away from Bernard, she wrote lengthy letters to him about how the Montreal house should be organized to make Eric more comfortable. From an architectural perspective, Anna's letters also reveal that she believed certain spatial arrangements (mostly separation and fresh air) would mitigate the spread of illness in the house. For example, on October 24, 1894, she worried to Bernard: "I hope dear baby is better, $\&$ that he goes out twice a day $\&$ his room is well aired. I don't like his sleeping in the nursery-for I know it mean bad air for all. . . . 


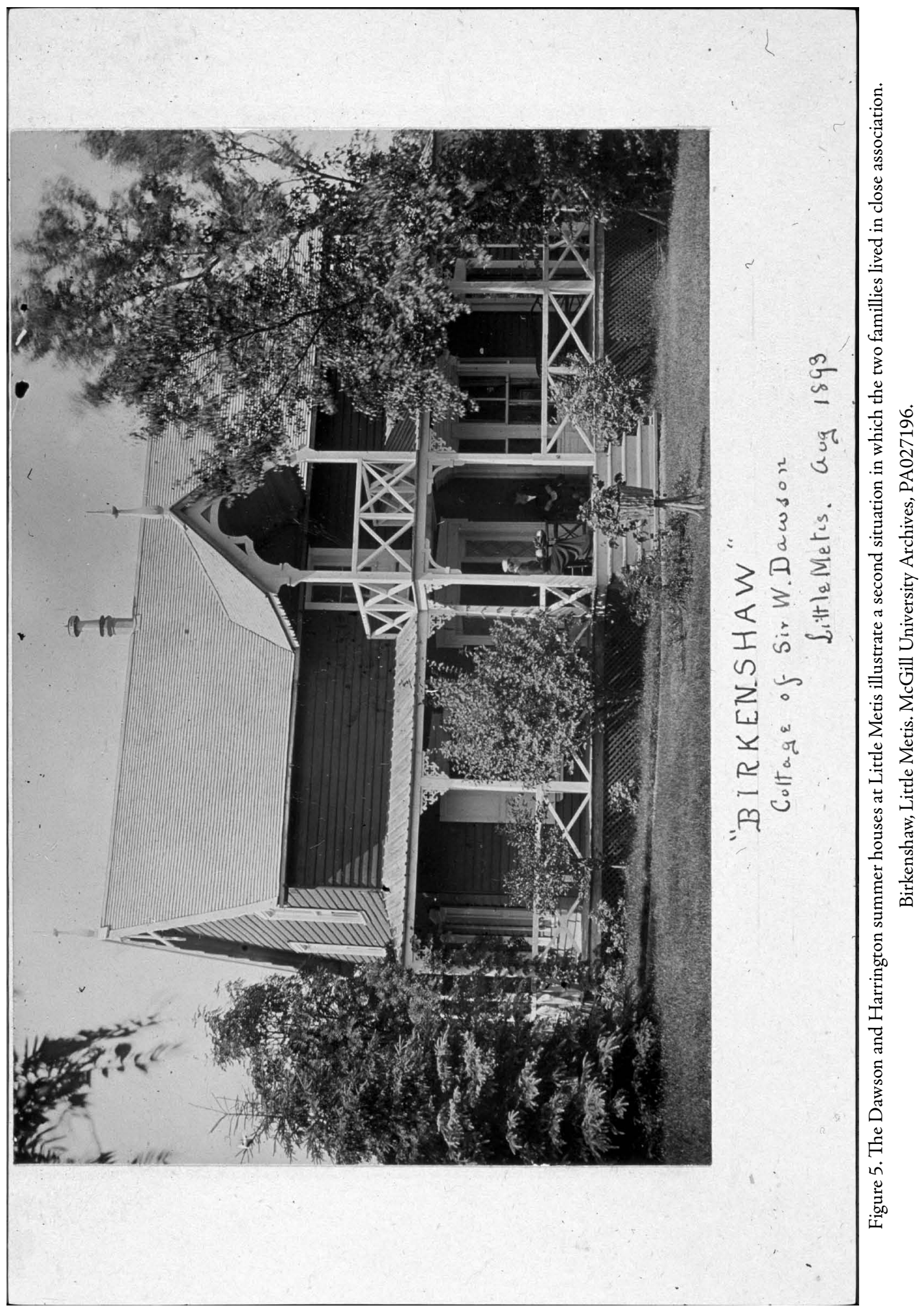


Please don't forget about Clare's window having a proper ventilator $\&$ I think R's suggestion as to a room to herself very useful. They [might?] sleep [better?] open window in any case, if a curtain or shade interposed to prevent draughts." 29 The Harrington children also wrote frequently to their absent mother articulating the minutiae of healthful living. Twelve-year-old Ruth wrote to Anna on November 18, 1894: "Was it Grandma that told you that our windows were not open for our window is open all day and Miss Bakers and the boys, and the nursery is open at intervals as often as possible." 30 The documentation of daily practices such as room ventilation by children is extremely rare.

In the fall of 1894, Anna's letters to her mother show she anticipated Eric's death. She instructed Lady Dawson: "Will you please have Eric's own blankets $\&$ pillows put on our bed $\&$ ours on his-I will sleep in the dressing room $\&$ I wd like a fire laid ready in my room. If there is lime it ought to have a thorough surfacing to avoid the necessity of its being done soon again. If you $\mathrm{cd}$ order a few oysters in the shell $\&$ new laid eggs $\&$ if your cook is equal to it have her make a little chicken jelly - with no pieces of chicken, or flavoring in it .... He can swallow the jelly better than fluid or solid .... Don't make the children realize the sorrow of the home coming."31 From Saranac Lake Anna warned her husband to be vigilant about the servants, whom she never relied on to make decisions regarding health: "Do be sure the children are out as much as possible especially baby $\&$ the little ones-I don't think Kate is at all so keen about that as Florence was $\&$ when the weather changes warn the older ones to be careful about warm clothing." ${ }^{32}$ In early December 1894, she ordered Eric's room at home thoroughly disinfected ("if the authorities here are right in confining possible infection") and some furniture in the drawing room recovered.

Life outside the house also meant outside the city, and the country. Both the Dawsons and the Harringtons travelled regularly to their adjacent summer homes in the anglophone summer enclave of Little Metis, on the lower St. Lawrence River, about $340 \mathrm{~km}$ downstream from Quebec City. ${ }^{33}$ Remarkably, the houses at Little Metis illustrate a second situation in which the two families lived in close association, here separated only by a gate. ${ }^{34}$ William Dawson was a fervent believer in the health-giving properties of the area, claiming that the ozone was superior. ${ }^{35}$ He purchased his house, Birkenshaw (Fig. 5), apparently to escape the heat of Montreal in the summers.

The Dawsons purchased the cottage next door to theirs for Anna and Bernard in about 1891. ${ }^{36}$ Although Anna's strong belief in the healing powers of the rural environment is clear in her letters-this is particularly evident in her letters about her son Conrad's illness after Eric's death-it is equally apparent that the country house acted as an extension of the city situation, rather than in opposition to it. Daily routines and the families' social circles were simply transposed east, confirming the widely held notion that a physical (not social) change was understood as restorative. But in nearly every other way the Dawson-Harrington country houses echoed their urban lives. Family letters suggest, however, that life was neither simple nor slow in Little Metis, although the area's dramatic natural landscape was obviously a significant change from the density of University Street in central Montreal, as was the children's holiday from school.

Anna stayed with Eric for nearly two months in Saranac Lake, New York, in the fall of 1894. That same year, the town saw the construction of the Saranac Laboratory, the first lab for the scientific study of tuberculosis in the United States. ${ }^{37}$ Five days after she wrote about bad air in the nursery, Anna disclosed to Bernard in a letter that Eric's kidneys were affected; he had albumin in his urine, his liver was enlarged, and there was thickening in his throat. By then, doctors, including the world-famous tuberculosis expert, Edward Livingstone Trudeau, had declared him 
a "hopeless case." ${ }^{38}$ Since Trudeau's sanatorium only accepted patients in the early stages of disease, it is unlikely that Eric was ever admitted to this hospital. ${ }^{39}$ Still, Lady Dawson sent Anna a "fur cloak" for "this sitting out business," suggesting that he was subject to Trudeau's famous fresh air cure. ${ }^{40}$ Anna writes, too, about the reasons to come home and how through renovation, their University Street house might be as good as the hospital: "I do believe we cd make as good a sitting out-place on Grandmama's roof as here, for the price of one week's board, or perhaps on mother's little gallery." ${ }^{11}$ These are lessons that Anna may have learned from her stay at Saranac Lake, where hotels and houses sported generous sleeping/cure porches. ${ }^{42}$ She may have imagined the intriguing 40' $x$ 4' passageway between the two houses, like Lady Dawson's rooftop, as a channel of fresh air between the two houses. It led to the all-important and shared back garden. While it is evident from the letters that the two families conceived of the compound as two separate residences - the Harringtons would be invited, for example, to come to tea with Lady Dawson-the two buildings also functioned as a single place. This situation was highlighted when a child was sick. The presence of one sick child might temporarily dislocate the others. Here is Anna's description of how the two housestheirs and her parents-functioned as one. "If Eric goes home it seems to me Clare ought to go. Mother wd take her, but that wd only be a half separation." ${ }^{43}$

Still, the younger family clearly used the house next door as a space for quarantining both sick and healthy children. In 1906, for example, daughter Lois had the measles and was sent to stay with Lady Dawson. When Eric was gravely ill, however, as in December 1894, this "half separation," as Anna called it, did not suffice. At that time, the other children were banished from the house altogether. In the letters, there is much discussion of the girls boarding at nearby Trafalgar School for a few weeks; or at the home of Louisa Goddard Frothingham Molson, a close family friend. This was a common strategy for keeping siblings out of harm's way in times of crisis, especially for the middle class. Poorer people might use an orphanage for temporary boarding, as historian Bettina Bradbury has shown for Montreal's working class. ${ }^{44}$ Comparisons between their home and other public institutions abound in the family's letters. Following Eric's death, when several of the other Harrington children had high fevers, Lady Dawson referred to her daughter's house as "a veritable private hospital." ${ }^{5}$

\section{THE CHILD AS CONNECTION}

Important in probing the way the two houses functioned as a health-driven enclave is the ubiquitous figure of Clare (fig. 6), the eldest child of Anna and Bernard Harrington, born in 1880 and a young teenager when her brother died. Clare was the human counterpart to the passageway and an excellent example of how a child might act as a connection between spaces. Like the void between the houses, Clare served as a bridge among the three generations, between the family members and the servants, and from her own extended family to other households. From the perspective of preventive medicine, Clare was also the hub of an information network that kept absent adults, especially her mother, informed as to the health and well-being of Lady Dawson, the Harrington children, and the servants.

Even as a 14 year old, Clare managed the everyday affairs of her younger siblings, as is evident from her charming letters. "Loise's boots will not nearly meet round her instep or anchel $\&$ Eva cannot get hers on. I tried Loise's on Eva but they are ever so much to long .... They need new boots very badly at once. . . . I think I could teach Ruth music if she would promise to practice $\&$ not take it as play." ${ }^{\prime 6}$ She also reported regularly to her mother regarding her siblings' growth, weight, and eating habits, comparing her younger brother to a sailor: "The children all look very well, Lois is getting too stout for 
beauty, but I suppose not for health. Bernard looks like a regular 'Jack-Tar', as solid as can be. Eva is very well, and rosy, but particular and $\mathrm{crab}[\mathrm{b}] \mathrm{y}$. She wont eat this or thats to much ect. Poppy is as merry $\&$ as well as can be." ${ }^{\prime 47}$ Indeed, the younger children frequently reported back to their mother on the effectiveness of Clare, even referring to their sister as a mother or "muddie." In 1900, Clare transcribed a letter from her younger brother: "My own dear Muddie, Hope you be back soon, $\&$ hope Grandmama be well too. ... Dear Muddie we be quite lonely without you. ... Clare been quite a good Muddie, quite sweet and kind. We love one another $\&$ me $\&$ Loie never forget to say our prayers-." 48

As young adults Clare and her sister Ruth (born 1882) served as crucial sources of medical information on their grandmother's situation, describing the condition of the older woman and communicating the advice of Lady Dawson's Montreal-based physicians. On May 18, 1907
Clare listed Lady Dawson's symptoms to Anna: "Grandmama is not well-Yesterday she did not feel herself but had nothing definite the matter with her. She went to bed early. This morning she had a slight pain in her right side." ${ }^{49}$ Three weeks later, Ruth reported: "Just a line to tell you that Dr Blackader finds it absolutely necessary that they should tap Grandmother's lung tomorrow because of the amount of the fluid there is. $\mathrm{Dr}$ Findley $\&$ Dr Roddick both agree that it must be done." ${ }^{50}$ Clare was clearly a comfort to her grandmother: "I do feel that G.M. really wants me at present. I seem to be the only person that she makes no effort for-She was sat up yesterday in the arm chair for about 20 minutes-Dr Bell insisted on this as he thinks the tube drains better that way, but poor G.M. was very, very tired after it." ${ }^{51}$

Clare's remarkable role as an intermediary between physicians and her mother extended to the condition of the other children as well,

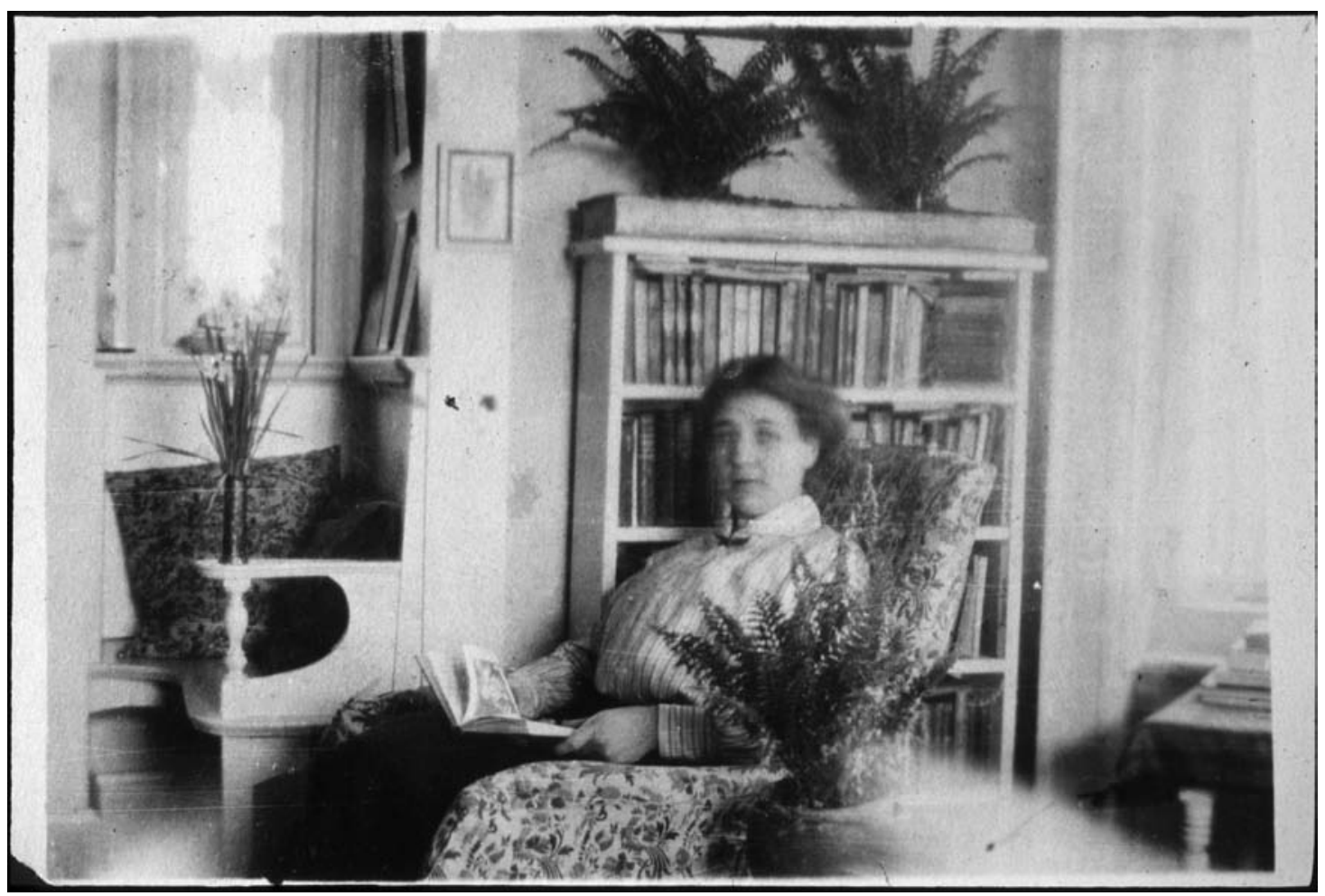

Figure 6. This may be the only extant interior photo of the University Street houses. Claire Harrington in livingroom, University Street, Montreal, QC, about 1915. McCord Museum, Montreal, Accession MP-1981.8.5053. 
whom she nursed diligently when they were ill: "Dr Browne came to see Eva, when I was at the Hospital, but Ruth saw him. He said she certainly ought not to be at school, $\&$ just to have her be out of doors as much as possible, but never to let her overtire.... I got a hammock today \& I think she will be able to be out most of the time, I sit up on the top veranda too a lot so that is quite nice, especially as we like the same books." 52

Helping her father to manage the house, children, and servants while Anna was away was a general responsibility of Clare's by age 14 , especially taking the younger children to visit other families: "Clare and I have had a great hunt to find the garments, tea, that you wanted and will mail them in an old valise that I found in the attic.... All of them [the children] except Clare \& Baby were at Sunday School this afternoon. Clare took Baby up to the Molson's where he seems to have done his best to show what he could do., ${ }^{33}$ Clare describes her visit to the Molson household nearly identically to her father's letter: "I took Baby to see Mrs Molson, she was delighted with him, he was so merry \& good." 54

Clare's responsibilities at age 15 extended to the scouting of potential employees: "I do not think there is any chance of getting Millie, as they have succeeded in getting several boarders and she is needed at home. Clare, however, is going to see her to-day. ... Mrs. J.L. Molson told Clare about some girl who expected to come to town shortly and wanted a housemaids place." 55 Frequently Clare communicated general information from the family's servants to her mother: "Miss Baker asked me to please tell you that if Florence leaves she would much prefer looking after all the children herself-and if the sewing was too much have her sister come up three times a week like last winter. As it is Miss Baker has the baby as much and more than Florence. Miss Baker will not stay after Xmas, she would like to leave before if possible." 56
Anna Harrington constantly worried about Clare's extensive responsibilities, a fact noted by family friends. In August 1898, Louisa Molson comforted Anna from Little Metis: "All goes well at yr cottage. I am watching Clare $\&$ have not yet seen the least sign of her being over tired, and I need hardly add she shows great wisdom \& kindness to Conrad and the younger children."57 Not surprisingly, when Molson herself fell ill, it was Clare who helped out: "You must see that Clare is not overtaxed," Anna warned Bernard in a letter concerning the older woman's recovery. ${ }^{58}$

\section{SHARED SPACES}

Clare was the most significant human connection between the Dawsons and the Harringtons. The shared garden, however, like the passageway between the houses, was a crucial spatial link between the grandparents and their grandchildren. The properties were represented as a single compound in a detailed 1907 map (Fig. 7) of the area. The fact that there was no fence, hedge, or other barrier between them is confirmed in a remarkable plan (Fig. 8) drawn by thirteen-year-old Clare on May 23, 1894. It shows a path extending into the shared space from the passageway, defined on the Dawson side by two beds of tulips. The rest is labelled by the young girl as "Grandpa's garden." On her own parents' side, Clare identifies "Con's little house" (her brother Conrad), a tree and perhaps a swing, and reports that grass seed is coming up. Although the two exterior spaces were somewhat separate, as shown in Clare's plan, the fact that she drew them together is fascinating and speaks to the conceptual unity of the family garden.

As a model of scientific classification, the gardens had direct links to both Dawson and Harrington's published work. They also had a connection to Little Metis. In an interesting reversal of the contemporary trend of bringing plants from untouched rural places to the city, the Harringtons sent plants yearly from Montreal to their Little Metis garden. Sometimes the children 


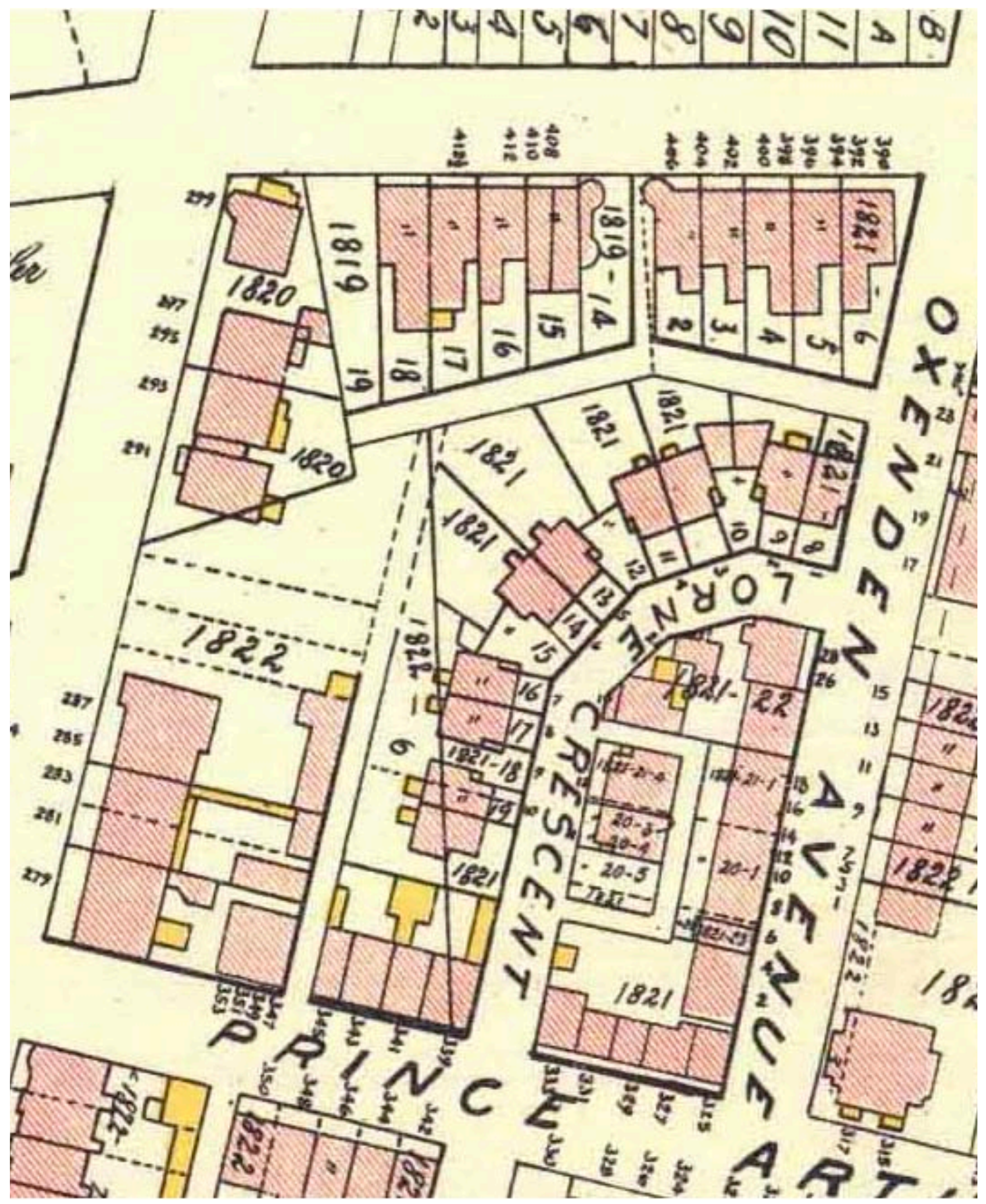

Figure 7. Note that this map lists the addresses incorrectly, as 291 and 293 University Street, rather than 293 and 295 University Street. Pinsonault, A.R. Atlas of the Island and City of Montreal and Ile Bizard: a compilation of the most recent cadastral plans from the book of reference. The Atlas Publishing Co. Ltd, 1907. Detail of plate 19. Bibliothèque et Archives nationales du Québec. 


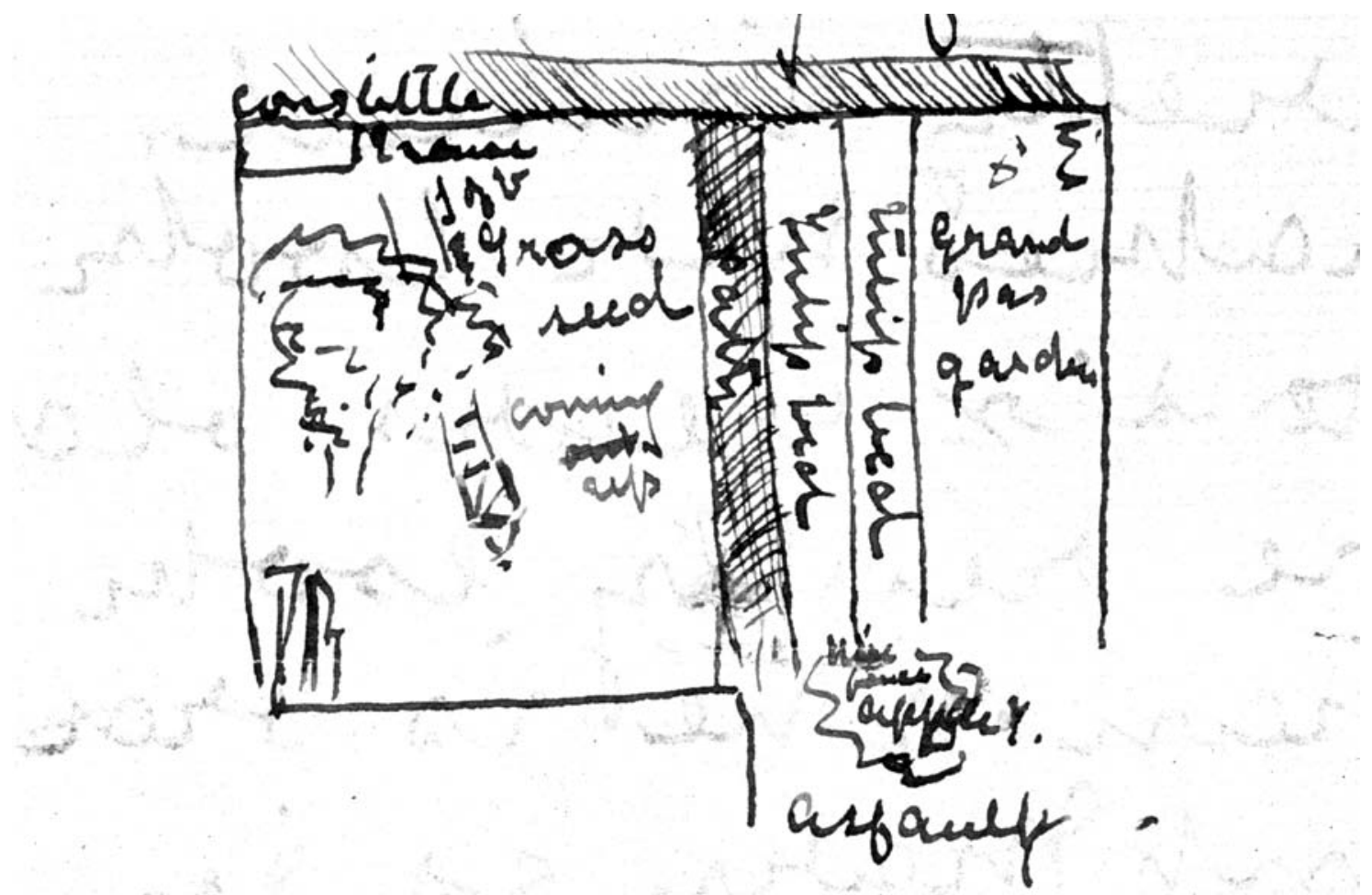

Figure 8. Clare Harrington drew this charming plan of the family garden in a letter to her father, May 23, 1894. Clare Harrington. McGill University Archives, Accession 0000-1211.

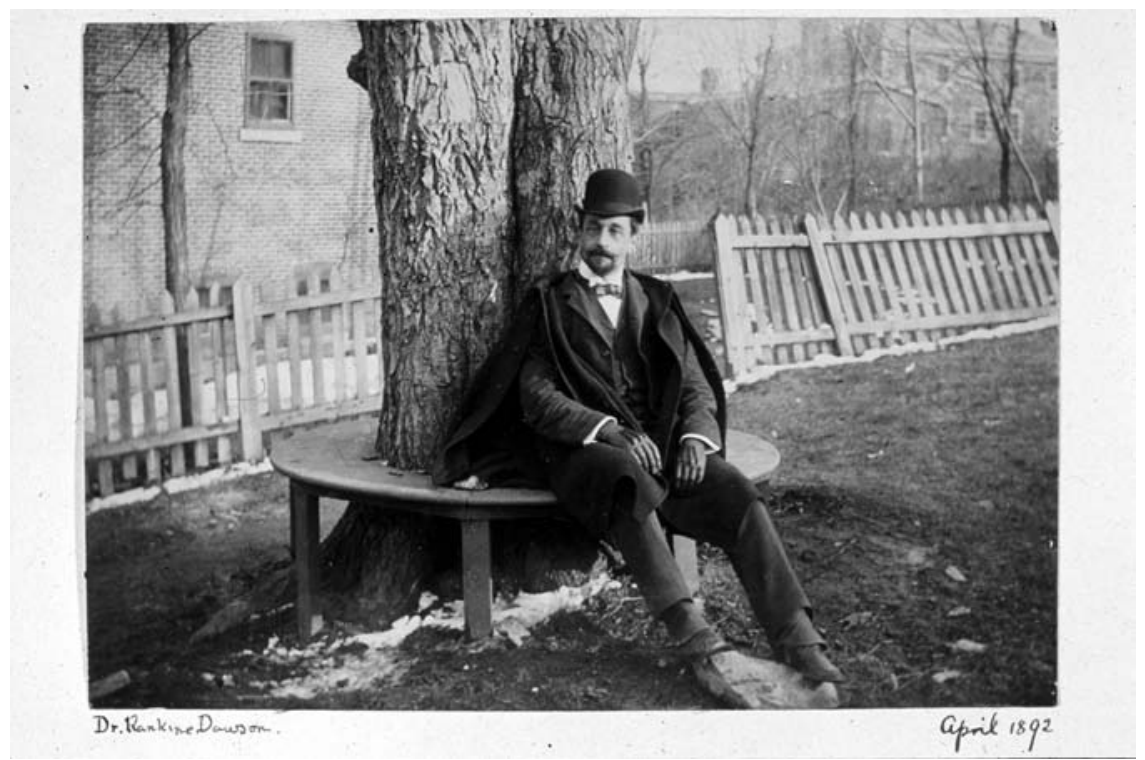

Figure. 9. Family letters describe how unexpected visits by Rankine Dawson would mean considerable arrangements between the Dawson and Harrington homes. Rankine Dawson leaning on a tree, April 1892. McGill University Archives, PA027196. 
sent samples back to Montreal to their father, Bernard, for identification. ${ }^{59}$ Even today, the path between Birkenshaw and the Harrington cottage is well worn. ${ }^{60}$ Both the urban and rural gardens, then, were important spaces of communication and education about health and nature between the children and these father figures, William Dawson and Bernard Harrington.

In addition to its function as an entrance to the shared garden, the passageway and the internal links it likely allowed Lady Dawson, too, to use her daughter's house as a form of "escape," especially when her depressed son, Rankine, would come to visit (Fig. 9). Throughout the letters to Rankine he was assured that there would always be a special room for him in his parents' house. In 1902, however, when he arrived for what was billed as a temporary stay, Lady Dawson moved in with the Harringtons. ${ }^{61}$ He also stayed at Little Metis. Clare, who took charge of the family while Anna travelled to Europe in 1902, reported that "one cannot help but notice how they all seem to rub each other up the wrong way," and that Uncle Rankine was "depressed with nothing to do"; Bernard Harrington concurred that his brotherin-law was "giving us a very bad time." ${ }^{2}$

Although the senior Dawsons were happy with the arrangement, their son-in-law, Bernard Harrington, was sometimes frustrated by the proximity of the two houses. "I wish we did not live so near to your mother," he wrote in 1894. "She seems to think that everything in our home is going to the dogs straight and excites herself greatly over it. The fact of the matter, however, is that all things considered we are getting on very well." ${ }^{3}$ And again, "I have been in ... next door and as usual come back cross. My dear Motherin-law I respect greatly, but I wish she had more tact. She always rubs me the wrong way. Still I know that she does not mean to do so." 64 Perhaps these domestic tensions were exacerbated, too, by the younger couple's constant financial dependence on the Dawsons. This explanation would not be surprising, given the centrality of the breadwinner role in Victorian conceptions of fatherhood and masculinity.

The larger lesson of the Dawson-Harrington compounds in both Montreal and Little Metis for historians of childhood and the family is in the considerable overlap they show between the so-called private and public, urban and rural, healthy and unhealthy spheres. The architect Andrew Taylor represents a human connection among some of these seemingly disparate architectures. In addition to the Dawson house, Taylor designed the building for Harrington's university chemistry department, now home to the Schools of Architecture and Urban Planning. All of these buildings were intricately connected to a medicalization of urban space at this time, especially in this corner of the McGill University campus. Walbrae Place was even demolished to make way for a new medical building. The Strathcona Medical Building, constructed in 1907, is directly across the street from the Dawson and Harrington houses.

The magnificent pavilion-plan Royal Victoria Hospital, modelled after the Royal Infirmary at Edinburgh, opened the same year as the two families moved into their new lodgings. The convenience of the hospital's proximity was not lost on the Dawsons, even though middleclass patients did not frequent the institution until after World War I. "Our new house is only a stone's throw from the Hospital," boasts William Dawson to his son Rankine in $1894 .{ }^{65}$ The hospital and the nearby municipal reservoir (another urban space devoted to health) are featured in a splendid photo (Fig. 10) from Eric Harrington's photo album, perhaps taken by the dying teenager.

As in the Dawson-Harrington homes, young patients were integrated with adults in the general hospital of the 1890s. In the architectural drawings of the Royal Victoria Hospital produced by London-based hospital specialist Henry Saxon Snell, children are accorded no special spaces or attention. In the institution's 
first annual report in 1894, there is no separate reporting of children. Few photographs survive of children at the sprawling, castle-inspired hospital. One image (Fig. 11) by famous photographer William Notman shows the end of an open ward with twelve beds and seventeen children. The arrangement of furniture and patients echoes those found in adult wards, except for the inclusion of tiny rocking chairs around a tea table especially scaled for children. ${ }^{66}$ Echoing Anna Harrington's advice to her children to open the windows of their rooms as frequently as possible, three of the four windows in the hospital ward shown in Notman's photograph are propped open.

The ventilated, connected, and fluid spaces for children and adults at the hospital and the home even reached beyond the extended, threegenerational family structure. The Harringtons invited Louisa Molson to move into their home in her old age. In 1902, at age 75 years, she commissioned a large extension (Fig. 12) to the Harrington house as her own apartment, but never moved in due to a stroke. This addition, which shows on a 1912 insurance map (Fig. 13), included a breakfast nook, dining room, and "another room," below a large veranda with views of the city and river. ${ }^{67}$ The apartment may have been something like what Sir and Lady Dawson had first imagined for their Taylor-designed retirement home or perhaps what they may have hoped for at the Windsor Hotel-separate sleeping quarters with shared meals.

\section{OUTSIDE THE HOME}

Historians have suggested that before sick, middle-class Canadian children were admitted to hospitals in North America, they were cared for by parents, mostly mothers, at home, mostly in bedrooms. What a real-world case study like this one reveals is the sheer extent of healthcare practices that took place beyond the thresholds of the bedroom and the home, where an extended family network was crucial to the regulation of healthy children. "Home" to Anna Harrington, and presumably to other mothers (though few would have the means or the depth of scientific knowledge she had at her disposal), meant a constellation of city and country houses, health resorts, hospitals, and university buildings. The passageway and garden, as architectural evidence, parallel the important role played by daughter Clare as an agent of domestic change and a hub of medical information. Like Henriette Dessaulles in our earlier study, the teenaged Clare seemed to gain control of her surroundings as family tensions around sickness increased, actively participating in the re-ordering of her domestic spaces. Here is a child, albeit a child of privilege, whose active role in the Victorian drama of maintaining a healthy home should push us to rethink notions of children as passive victims, whether of decisions made by their elders or of the very real public health risks run by young and old alike in this period.

Van Slyck asks whether the intense interest in the material culture of childhood on the part of museum curators and scholars today might arise from anxiety that childhood itself is on the verge of extinction. ${ }^{68}$ Perhaps in the late-Victorian era, when sickness and mortality were seen as normal, inevitable aspects of family life, these distinctions between age groups were less necessary or even conceivable. As childhood illnesses came to be seen as curable or preventable, sick children were increasingly islanded. Along with the emergence of pediatrics came the proliferation of purpose-built hospitals for children, in which distinctive procedures were undertaken by specialist physicians and nurses in the interwar period. Anna and Clare Harrington's detailed communication explains how the Victorian house and family were not separated like islands, but were often connected to other households and institutions in unexpected and scientific ways. In the case of the Dawson-Harringtons, indeed, sick children inspired travel and selfeducation, reinforcing this family's connection to the worlds outside their homes. 


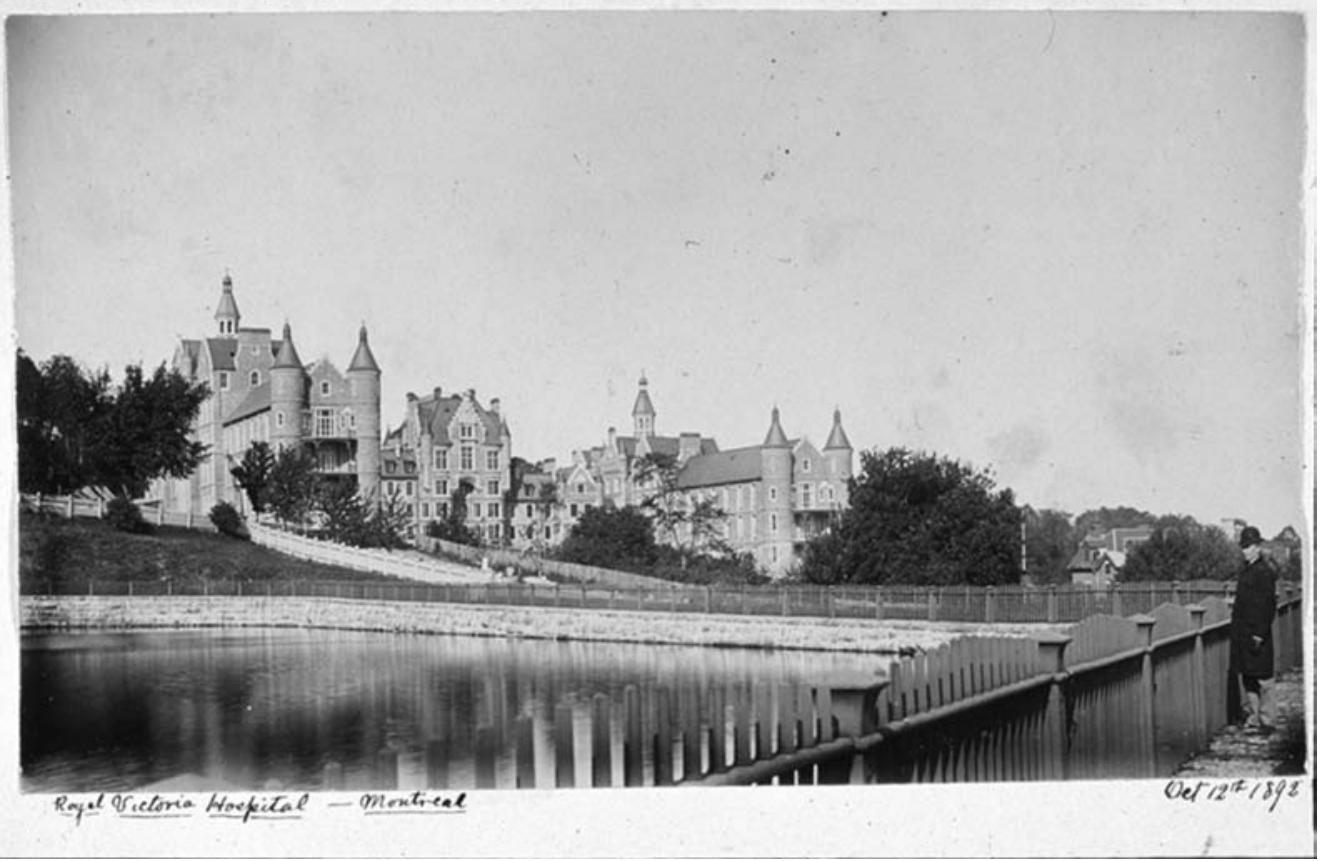

Figure 10. The Royal Victoria Hospital and city reservoir, likely photographed by Eric Harrington two years before his death. McGill University Archives, PA027196.

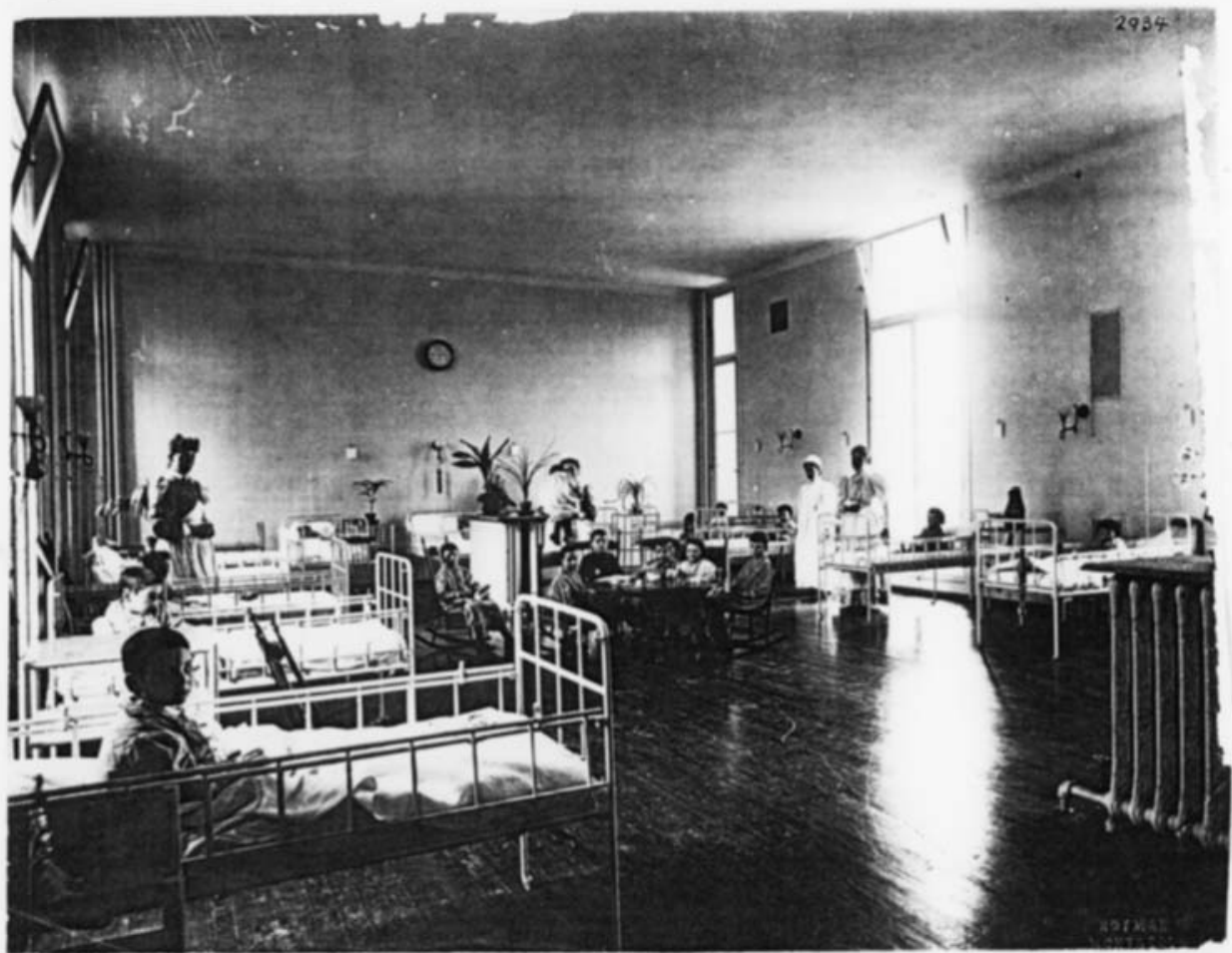

Figure 11. Children's ward, Royal Victoria Hospital, Montreal, QC, 1894. Wm. Notman \& Son. McCord Museum, Montreal, Accession II-105910. 


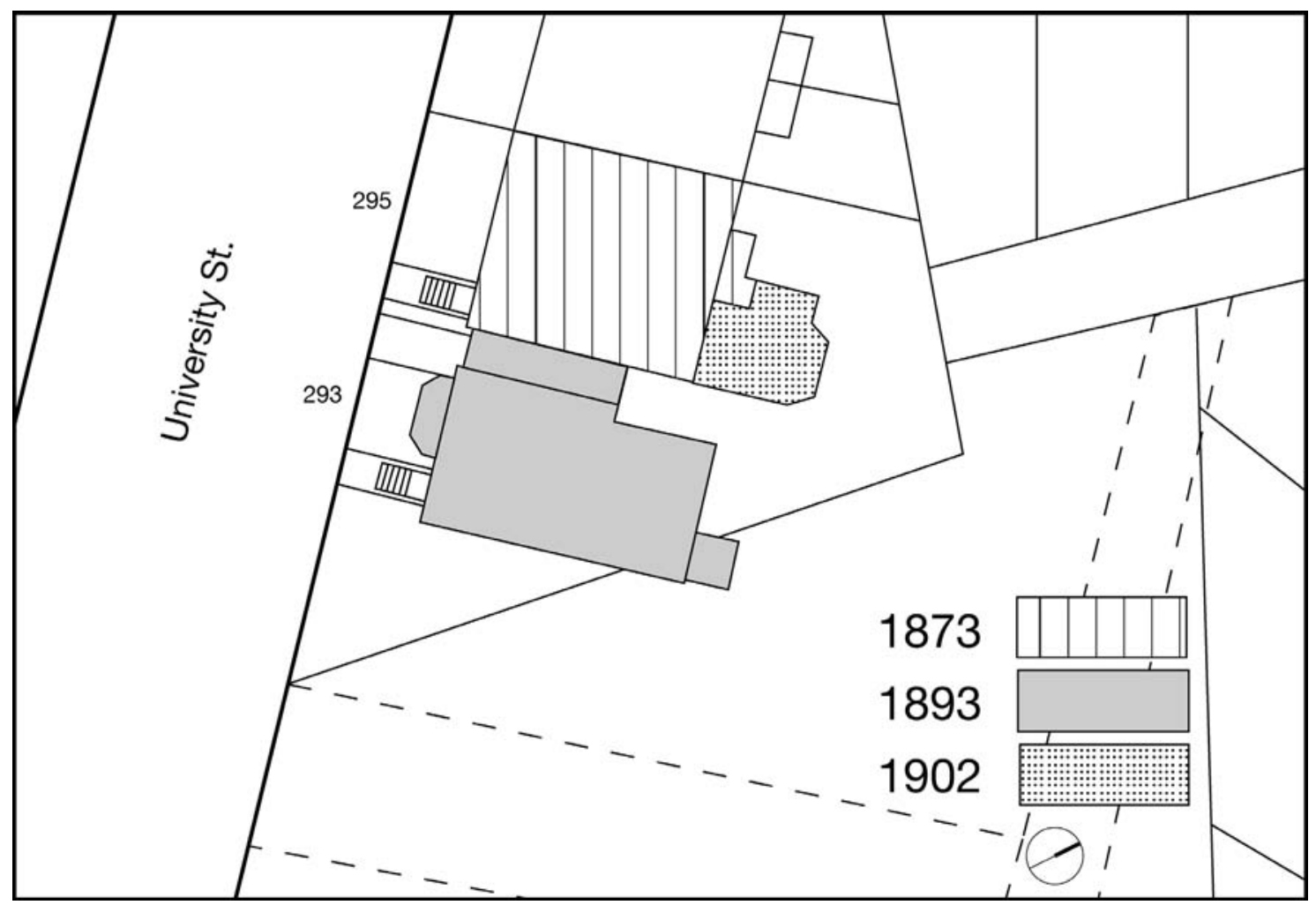

Figure 12. Diagram showing the evolution of the Dawson-Harrington site, including the Molson apartment added in 1902, based on historic maps and on-site fieldwork. Illustration by Ricardo Vera, McGill University School of Architecture student, 2002; redrawn by David Theodore. 


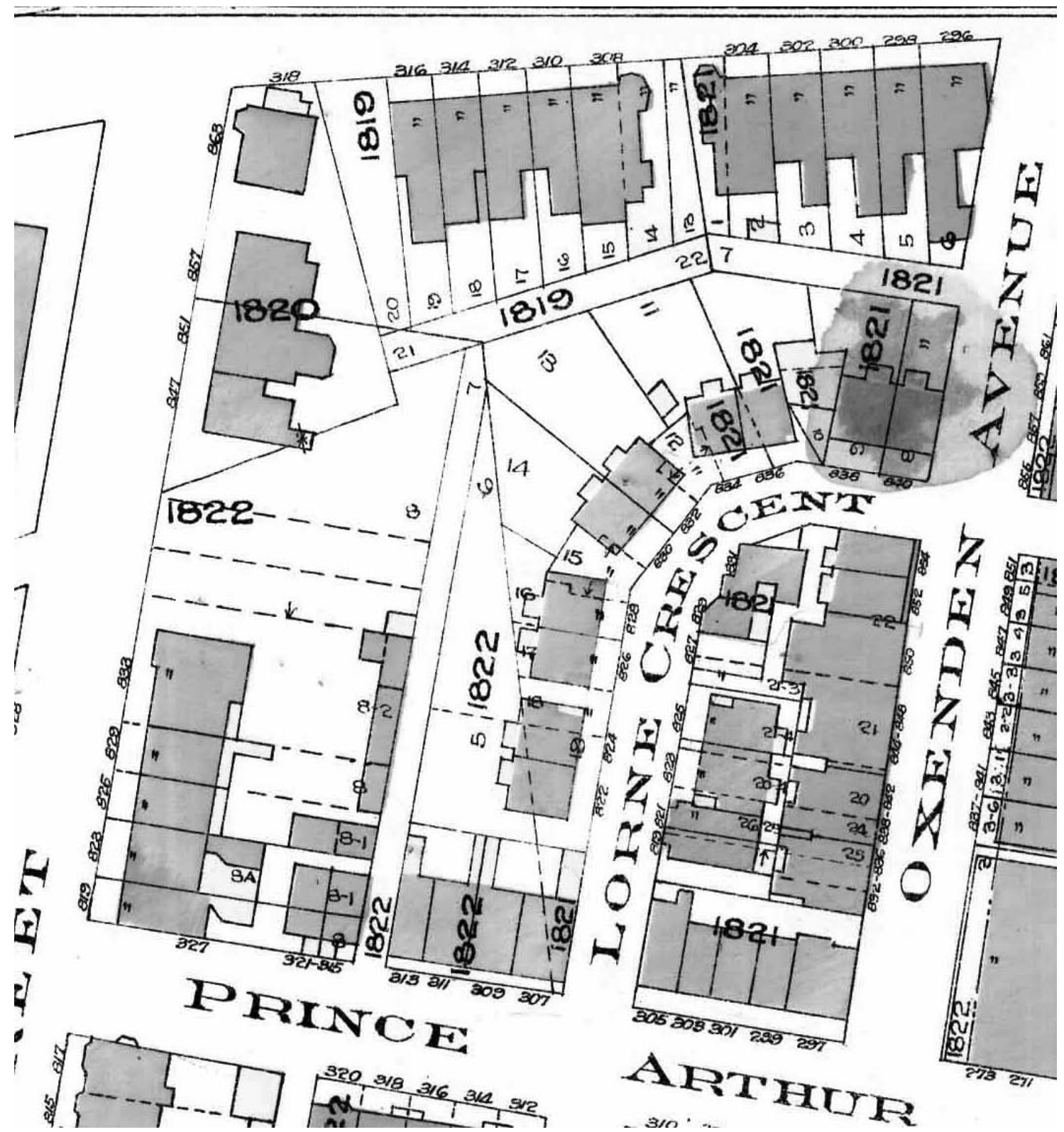

Figure 13. This map shows the extension to the Harrington home commissioned by Louisa Molson in 1902. Atlas of the City of Montreal and Vicinity: in four volumes, from official plans - special surveys showing cadastral numbers, building \& lots. Chas E. Goad Co. Vol. 1, plate 20, 1912. Bibliothèque et Archives nationales du Québec. 


\section{ENDNOTES}

${ }^{1}$ Our thanks to the Fonds FCAR (now FQRSC) for its financial support and, for research assistance, to Anna Bradbury, Ricardo Castro, Valerie Minnett, David Theodore, Julia Tischer, Ricardo Vera, Suzanne Williams, and especially Vanessa Reid, who left no Dawson-Harrington source untouched. Thanks also to Gordon Burr, Anne Byers, Derek Drummond, Conrad Graham, Nora Hague, Jill Harrington, and Victoria Solan. Robert McDonald made insightful comments on an earlier version of this paper, presented at the conference of the Canadian Historical Association, Toronto, 2002. Thanks also to Stanley B. Frost for his helpful comments and kind encouragement. A slightly longer version of this article appeared in Designing Modern Childhoods: History, Space, and the Material Culture of Children, edited by Marta Gutman and Ning de ConinckSmith, (New Brunswick, New Jersey and London: Rutgers University Press, 2008), 61-81.

${ }^{2}$ Canadian Encyclopedia, 2nd ed., ed. James H. Marsh.., (Edmonton: Hurtig Publishers, 1988), s.v. "Sir John William Dawson."

${ }^{3}$ See especially Donald J.C. Phillipson's entry on Dawson in the Canadian Encyclopedia. The major biography is that of Susan Sheets-Pyenson, John William Dawson: Faith, Hope and Science (Montreal and Kingston: McGill-Queen's University Press, 1996). See also Rankine Dawson's edition of his father's memoirs, entitled Fifty Years of Work in Canada, Scientific and Educational, being Autobiographical Notes by Sir William Dawson (London and Edinburgh: Ballantyne, Hanson, 1901). Dawson himself wrote more than 400 books and articles. He also figures prominently in histories of women at McGill, of the field of natural history, of the Royal Society of Canada, and of the Geological Society of Canada.

${ }^{4}$ For Dawson's description of Dawson Hall, see "Dawson, Fifty years," 98-99. A brief history of the building is presented in Stanley B. Frost, "When Rocks Hit the Roof," McGill News 83, no. 4 (Winter 2003/04): 52.

${ }^{5}$ The estimate of 15 linear metres is from Gordon Burr of the McGill University Archives, where John William Dawson's family can be traced through four generations. Anna Dawson Harrington is further represented in the McCord Museum's collections, which include her illustrations and some personal artifacts.

${ }^{6}$ It is well established, for example, that Dawson met his future wife, Margaret Ann Young Mercer, in Edinburgh in 1840, when Dawson was studying at the University of Edinburgh. The couple married against the wishes of her mother. See Dictionary of Canadian Biography vol. 12, general ed. Frances G. Halpenny (Toronto: University of Toronto Press, 1990), s.v. "Sir John William Dawson." Stanley Frost discusses their early relationship in "A Transatlantic Wooing," Dalhousie Review 58, no. 3 (Fall 1978).

${ }^{7}$ McGill News 42, no. 2 (Spring 1961): 20.
${ }^{8}$ The photo album from which this image was extracted includes many images of the Dawson family, as well as photographs of the Royal Victoria Hospital, and two university buildings under construction (Redpath Library and the Physics Building). The hand-written captions match that of the name and date on the inside cover,"George Eric Harrington, Xmas 1892" (McGill University Archives PA027196). Eric was rarely identified by the name George, although it does appear on his gravestone.

${ }^{9}$ The current address of the property is 3641 University Street, now the Off-Campus Housing office. In 1944 an apartment building was erected in its rear yard. A good description of the property in 1952 is in the building inspector Alfred Trottier's report, McGill University Archives RG 12 Container 12.

${ }_{10}$ The relations between Taylor and the Dawsons are numerous. He designed at least six buildings at McGill University, and Taylor's wife's sister married William Bell Dawson.

${ }^{11} 293$ University first appears in the Lovell's Street Directory in 1873-74. Montreal Directory for 1873-74: Containing an Alphabetical Directory of the Citizens, and a Street Directory, with Subscribers and Advertisers, Classified Business Directories and a Miscellaneous Directory... (Montreal: J. Lovell, 1873).

${ }^{12}$ The wedding is described in Peter Ward, Courtship, Love, and Marriage (Montreal and Kingston: McGill-Queen's University Press, 1990), 108. Anna Harrington gave birth to nine children and all but a daughter (Edith, who died in $1890)$ survived infancy. When they obtained the University St. house on 6 July 1893, she had just given birth to her youngest child, William, born 17 or 19 May 1893.

${ }_{13}$ The Dawsons also considered the Windsor Hotel and the apartment building The Sherbrooke. Their son George Mercer Dawson offered them a house in Ottawa, but William Dawson felt he needed to remain in Montreal for his work.

${ }^{14}$ Margaret to George, 16 May 1893 (McGill University Archives MG 1022 Container 55). Lady Dawson's comment about taking meals together suggests an internal connection was included in the original house as designed by Taylor. Sheets-Pyenson, however, says the link was only added following the death of William Dawson in 1899 (SheetsPyenson, 96). George Mercer Dawson became one of Canada's pioneering geologists. See Lois Winslow-Spragge, No Ordinary Man: George Dawson, 1849-1901 (Toronto: Natural Heritage, 1993). His own health was as complex as young Eric Harrington's, as Dawson contracted tuberculosis of the spine, or Pott's disease, at age 9, which stunted his growth and left him hunch-backed.

15 The house remained in the Dawson family until 1920, at which time Clare and Conrad Harrington sold it to Phi Kappa Pi McGill Limited.

16 Denyse Baillargeon, Babies for the Nation: The Medicalization of Motherbood in Quebec, 1910-1970, trans. 
W. Donald Wilson (Waterloo: Wilfrid Laurier University Press, 2009), 22.

${ }^{17}$ See, for example, Terry Copp, The Anatomy of Poverty: The Condition of the Working Class in Montreal, 1897-1929 (Toronto : McClelland and Stewart, 1974), and JeanClaude Robert, "The City of Wealth and Death': Urban Mortality in Montreal, 1821-1871," in Essays in the History of Canadian Medicine, ed.Wendy Mitchinson and Janice Dickin McGinnis (Toronto: McClelland and Stewart, 1988), 18-38.

${ }^{18}$ Abigail A. Van Slyck, "Kid Size: The Material World of Childhood," Winterthur Portfolio 39, no. 1 (Spring 2004): 71.

${ }^{19}$ Annmarie Adams, Architecture in the Family Way: Doctors, Houses, and Women, 1870-1900 (Montreal and Kingston: McGill-Queen's University Press, 1996).

${ }^{20}$ Annmarie Adams and David Theodore, "Designing for 'the Little Convalescents': Children's Hospitals in Toronto and Montreal, 1875-2006," Canadian Bulletin of Medical History 19 (2002): 201-243.

${ }^{21}$ Peter Gossage, Families in Transition: Industry and Population in Nineteenth-Century Saint-Hyacinthe (Montreal and Kingston: McGill-Queen's University Press, 1999).

${ }^{22}$ This is in contrast to what Howard Chudacoff found in selected New England cities, where young couples did live with their parents. See for example Howard Chudacoff, "New Branches on the Family Tree: Household Structure in Early Stages of the Life Cycle in Worcester, Massachussetts, 1860-1880," in Themes in the History of the Family, ed. Tamara K. Hareven (Worcester: American Antiquarian Society, 1978), 55-72.

${ }^{23}$ Annmarie Adams and Peter Gossage, "Chez Fadette: Girlhood, Family, and Private Space in Late NineteenthCentury Saint-Hyacinthe," Urban History Review 26, no. 2 (March 1998): 56-68. On women and privacy in the Victorian home, see also Annmarie Adams and Silvia Spampinato, "Carrollcroft as Women's Space: an Architectural History," Journal of Eastern Townships Studies 35 (2010): 21-48.

${ }^{24}$ See Margaret to George, 13 June 1893, McGill University Archives MG 1022 Container 55, and William to Bernard, 3 July 1893, McGill University Archives MG 1022 Container 66.

${ }^{25}$ Margaret to George, 21 July 1894, McGill University Archives MG 1022 Container 55.

${ }^{26}$ Anna to Bernard, 4 June 1894, McGill University Archives MG 1022 Container 66.

${ }^{27}$ Anna to Bernard, 8 June 1894, McGill University Archives MG 1022 Container 66.

${ }^{28}$ George to Anna, 6 January 1895, McGill University Archives MG 1022 Container 62. The phrase "unlimited cash" occurs in a letter from Anna to Bernard, [no day] 1894, McGill University Archives MG 1022 Container 66. Jill Harrington, the daughter of Conrad F. Harrington and
Joan Hastings Harrington, also reports that the family lore includes a story that Eric choked on a cherry stone and died. Jill Harrington, personal communication, June 2002.

${ }^{29}$ Anna to Bernard, 24 October 1894, McGill University Archives MG 1022 Container 66.

${ }^{30}$ Ruth to Anna, 18 November 1894, McGill University Archives, MG 1022 Container 62.

${ }^{31}$ Anna to Lady Dawson, [no day] November 1894, from Saranac Lake, McGill University Archives MG 1022 Container 52.

32 Anna to Bernard, 29 October 1894, McGill University Archives MG 1022 Container 66.

${ }^{33}$ Alice Sharples Baldwin, Metis wee Scotland of the Gaspé ([Montreal], privately printed, 1960).

${ }^{34}$ All three of the families' houses were, in fact, closely linked. While the older Dawsons lived at Dawson Hall, the Harringtons resided at Walbrae Place, just to the east of Dawson Hall on the McGill campus.

${ }^{35}$ Winslow-Spragge, 43.

${ }^{36} \mathrm{We}$ are grateful to Jill Harrington who reports that Birkenshaw was left by Lady Dawson to Clare, who left it to her surviving sisters (Lois and Eva), and then to a group of nieces and nephews. The Harrington house became the property of Anna's siblings and later, their children. It is still owned by Joan Hastings Harrington, the widow of Conrad Fetherstonhaugh Harrington (1912-2000), the son of Anna's second son, Conrad Dawson Harrington, and Muriel Fetherstonhaugh. Jill Harrington, personal communication, June 2002.

37 "Fate of Trudeau's Saranac Laboratory Uncertain," Newsletter Adirondack Architectural Heritage (May 1992): 1.

${ }^{38}$ On Trudeau, see "Edward Livingston Trudeau: A Biographical Sketch," Journal of Outdoor Life 7, no. 6 (June 1910): 157-178.

${ }^{39}$ Anna's letters are quite detailed on their various activities and the therapies tried by doctors there. This should perhaps be the topic of a separate paper.

${ }^{40}$ The letters reveal that Eric enjoyed photography, sketching, and reading science journals when he felt well.

${ }^{41}$ Anna to Bernard, 7 November 1894, from Saranac Lake, McGill University Archives MG 1022 Container 66.

${ }^{42}$ Mary B. Hotaling, "Porches That Cured," Adirondack Life (December 1986): 11-12, 14.

${ }^{43}$ Anna to Bernard, 30 November 1894, from Saranac Lake, McGill University Archives MG 1022 Container 66.

${ }^{44}$ Bettina Bradbury, "The Fragmented Family: Family Strategies in the Face of Death, Illness, and Poverty, Montreal, 1860-1885," in Childhood and Family in Canadian History, ed. Joy Parr (Toronto: McClelland and Stewart, 1982), 109-28. 
${ }^{45}$ Lady Dawson to George Dawson, on mourning paper, 21 February 1895. McGill University Archives MG 1022 Container 55.

${ }^{46}$ Clare to Anna, 16 September 1894 , McGill University Archives, MG 1022 Container 62.

${ }^{47}$ Clare to Anna, [no day] June 1895, McGill University Archives, MG 1022 Container 62.

${ }^{48}$ Poppy to Anna (transcribed by Clare), [no day] March 1900, McGill University Archives, MG 1022 Container 63.

${ }^{49}$ Clare to Anna, 18 May 1907, McGill University Archives, MG 1022 Container 63.

${ }^{50}$ Ruth to Anna, 5 June 1907, McGill University Archives, MG 1022 Container 63.

${ }^{51}$ Clare to Anna, 2 July 1907, McGill University Archives, MG 1022 Container 63.

${ }^{52}$ Clare to Anna, [no day] June 1907, McGill University Archives, MG 1022 Container 63.

${ }^{53}$ Bernard to Anna, 16 September 1894 , McGill University Archives, MG 1022 Container 62.

${ }^{54}$ Clare to Anna, 16 September 1894, McGill University Archives, MG 1022 Container 62.

${ }^{55}$ Bernard to Anna, 23 September 1895, McGill University Archives, MG 1022 Container 62.

${ }^{56}$ Clare to Anna, 16 September 1894, McGill University Archives, MG 1022 Container 62.
57 Louisa Molson to Anna, 17 August 1898, McGill University Archives, MG 1022 Container 62.

58 Anna to Bernard, 6 June 1902, McGill University Archives, MG 1022 Container 66.

59 Bernard [Jr.] to Bernard, [no day] November 1900, McGill University Archives, MG 1022 Container 66.

${ }^{60}$ Jill Harrington, personal communication, June 2002.

${ }^{61}$ Anna to Bernard, 2 September 1902, McGill University Archives, MG 1022 Container 66.

${ }^{62}$ The three quotations in the previous sentence are from the following letters: Clare to Anna, 7 July 1902; Clare to Anna, 12 July 1902; Bernard to Anna, 23 August 1902; all are from McGill University Archives, MG 1022 Container 63.

${ }^{63}$ Bernard to Anna, 11 November 1894, McGill University Archives, MG 1022 Container 62.

${ }^{64}$ Bernard to Anna, 14 December 1894, McGill University Archives, MG 1022 Container 62.

${ }^{65}$ See William to Rankine, 8 April 1894 , McGill University Archives, MG 1022 Container 68).

66 Adams and Theodore, "Designing for the Little Convalescents,"' 205.

${ }^{67}$ Alterations were also made to the existing house at this time. See Winslow-Spragge, 9-10.

${ }^{68}$ Van Slyck,"Kid Size," 72 